\title{
Fragmentos axiológicos e eixos de afirmação do Direito da Medicina
}

\author{
Axiological fragments and claim axes of medical Law
}

Fragmentos axiológicos y ejes de aseveración del derecho Médico

João Vaz Rodrigues ${ }^{1}$

\begin{abstract}
RESUMO: Existem aspectos peculiares e universais no ordenamento normativo da saúde, tal como nas relações jurídicas entre os profissionais de saúde e os pacientes. Os que ressaltam em originalidade e perpassam outras disciplinas decorrem logo da dignidade e da autonomia ( $\mathrm{vg}$. privacidade e autonomia: consentimento esclarecido e, radicalmente, a recusa e revogação). Neste texto vou abordar além do cuidado e da solidariedade, nesse feixe que conexiona o Digesto, alguns aspectos sobre princípios como o de respeito e reconhecimento, e entre o mais, apontar contributos para uma autonomia disciplinar que parece impor-se: a do Direito da Medicina.
\end{abstract}

Palavras-chave: Direito da Medicina, Consentimento, Recusa. Respeito

ABSTRACT: There are unique and universal aspects of the legal system as in the juridical relationship between medical agents and patients. Those aspects which emerge with the originality that crosses several disciplines are dignity, privacy and autonomy (vg: informed consent and, radically, refusal or revocation of consent). Throughout this text l'll bring to those matters, not only some ideas about care and solidarity, but also some aspects of principles such as respect and recognition, and among the most, pointing contributions to Law Medicine as an autonomous model of rules, in order to interconnect the existing legal puzzle.

Keywords: Law, Medicine, Informed consent. Informed refusal. Respect

RESUMEN: Hay aspectos únicos y universales de la ley y de la relación jurídica entre los profesionales de la salud y los pacientes. Los que se destacan en el tallo de originalidad son la dignidad y la autonomía (aún privacidad: consentimiento informado, y radicalmente, la denegación y revocación). En este artículo voy a tratar de revisar los trozos resultantes, más allá de los deberes de cuidado en salud y de la solidaridad, algunos aspectos de los principios cómo el de respeto y el de reconocimiento, y entre los demás, contribuciones para agasajar una autonomía disciplinaria que va a imponerse: el Derecho de la Medicina.

Palabras clave: Derecho, Medicina. Consentimiento. Rechazo. Respecto

\footnotetext{
${ }^{1}$ Professor Auxiliar. Escola de Ciências Sociais. Universidade de Évora. Portugal. Advogado. Membro Conselho Superior de Magistratura. E-mail: vaz.rodrigues@vrcpsc.com
} 


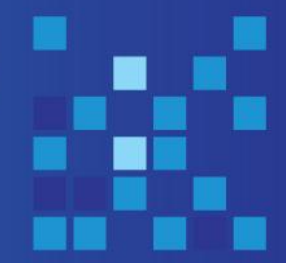

\title{
Introdução
}

\begin{abstract}
Não te dei Adão, nem um aspecto propriamente teu, nem nenhuma prerrogativa tua, para que aquele lugar, aquele aspecto, aquelas prerrogativas que tu desejas, tudo, segundo a tua vontade e juízo, obtenhas e conserves. A natureza determinada dos restantes seres está contida nas leis por mim prescritas. Tu determiná-la-ás a ti mesmo, sem estar condicionado por nenhuma fronteira, segundo o teu arbítrio, a cujo poder te consigno. Pus-te no centro do mundo para que descobrisses melhor o que há nele. Não te fiz nem celeste nem terrestre, nem mortal nem imortal, para que tu próprio, livre e soberano artífice, te modelasses e esculpisses, na forma escolhida por ti. Poderás degenerar para as coisas inferiores, até aos brutos; poderás regenerar-te, segundo a tua vontade, para as coisas superiores que são divinas. Giovanni Pico de La Mirandola, Oratio pro hominis dignitate ${ }^{2}$
\end{abstract}

A manifestação relevante da vontade legítima redunda em uma projecção do âmago do respeito. Trata-se da exposição sincrética das faculdades que oferecem mensurabilidade sobre as opções e o arbítrio das disponibilidades contingentes ao desiderato. Uso a expressão arbítrio com plena consciência do peso que a vontade possui para o efeito e darei sinonímia integral a alvedrio; mas pretendo-a discricionária e sindicável. Inclui, pois, por natureza, o poder individual de apontar as fronteiras da coexistência com os outros e a rota das consequências da interactividade. Eis a ambição da vivência humana individual em vista e por força das plataformas relacionais com a comunidade e acesso a bens e utilidades elegíveis. Servindo-se intervenientes, sem prejuízo do entorno, majoram-se os interesses recíprocos. Traduz-se reconhecimento.

Esta realidade obriga a (re)ponderar permanentemente pontos prévios. Recolho a doutrina de Orlando de Carvalho sobre a relação jurídica e o poder individual que nesta se produz como contemporânea pré-aquisição da humanidade ao ser-em-devir que é o ser humano e se projecta e explica em convivência com os poderes|deveres alheios. Personificação, portanto. Para tanto, é reconhecível um mecanismo individual de inalienável produção potencial de Direito (jurisgenia), já que o ser humano expõe-se em alteridade, por afirmação, mas impelido à construção e modificação do meio ambiente. Construções comunitárias para cujas matérias convoca a confluência das liberdades 


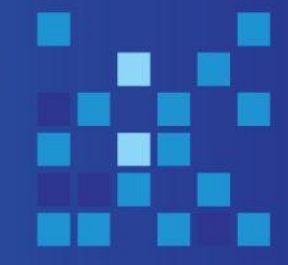

essenciais ${ }^{3}$. Neste sentido, a pretexto da forçosa conformação do mundo pelo ser humano, constatou Hannah Arendt (1):

Si el mundo se entrega a la obligatoriedad de sus propias leyes materiales, no recibe la influencia de la fuerza legisladora del ser humano y sólo resta esa melancolía general que desde los salmos de Salomón constituye la sabiduría de este mundo. Si el ser humano acepta esta marcha forzosa como ley suprema y se pone a su disposición, no está sino preparando la decadencia del género humano. Una vez que se produzca ésta, la marcha forzosa del mundo se convertirá — sin más impedimentos y sin que lo amenace la libertad humana- en un «eterno retorno», en la ley de una naturaleza que el ser humano no manipulará, pero en la que tampoco encontrará un hogar, pues no puede vivir en la naturaleza sino transformarla

Será improvável ao ser humano deixar de transformar a natureza tal como deixar de transformar-se por força da correlação consequente ${ }^{4}$. A par deste fenómeno consequente de recíproca transformação subsiste a personalidade humana anterior ao querer ou à manifestação jurídica. É inevitabilidade da inteligência reconhecer a personificação para

\footnotetext{
${ }^{3}$ Classificam-se os direitos de personalidade em inatos e não inatos (tal como em essenciais, pessoais, absolutos e indisponíveis: ao menos tendencialmente). Ensina Orlando de Carvalho: aqueles «...são subjectivações de aspectos do poder de autodeterminação» e estes podem ser adquiridos, como o direito ao nome e/ou ao pseudónimo que derivam do direito inato à identidade (identificação pessoal), adstrito após actuação formal no registo civil (já a alcunha oscilará entre a formalidade e a coexistência). Acrescenta: "Claro que esta nomenclatura extravasa do positivismo legalista dominante, que só admite direitos como emanação da norma e, por conseguinte, direitos adquiridos...», TGDC, Coimbra, 2012, pp. 148 ss. Ultrapassa assim os arreios positivistas sem cair nas tentações de um jusnaturalismo que retire legitimidade ao poder legiferante, ou pior, que reescreva o direito materializado. Para tanto, recorre à construção inovadora própria de uma relação jurídica analisável e susceptível de traduzir a realidade e de ser aplicada, enquanto funcional (interesses) ou estrutural (preceito), ID|ibid: Introdução, pp. 98 ss. Neste sentido, a relação jurídica enquanto dupla manifestação interage com as esferas de legitimação porquanto ambas concorrem entre si. Nestas linhas não tem cabimento a vexata quaestio entre positivismo e jusnaturalismo, mas registo a dificuldade em movimentar a realidade a partir da norma positivada sem recorrer ao éter revivificador que recoloque um reconhecimento heurístico da actualidade em harmonia com a raiz humana. Daqui ser-me bem-vindo um modelo a ultrapassar as dificuldades das correntes. A pessoa humana, retomando as palavras do Mestre: «Não precisa de leis, não precisa de rerum natura para se impor», Para uma Teoria da Pessoa Humana, ibid, p. 266. No mesmo esteio leio Luísa Neto: «Muito ao invés de digladiar positivismo e jusnaturalismo, há que apontar para uma perspectiva de tolerância que posiciona os direitos fundamentais num ambiente de consenso que torna subsidiária a acção do Estado. Este, por qualquer que seja a sua forma e vocação última jamais poderá ser considerado um fim em si mesmo. Só o Homem o há-de ser.». Contudo, logo em seguida, a A. radica uma necessária obediência prévia, fundante, do direito positivo ao direito natural: «[Ultrapassadas discussões estéreis opondo o humanismo e o individualismo face ao universalismo, hoje é-nos claro que o direito natural funda e garante ab superiore o direito positivo]», $O$ Direito Fundamental à Disposição Sobre o Próprio Corpo, Revista FDUP, I, 2004, Março, pp. 221-246, Coimbra, p. 228; O Direito Fundamental à Disposição Sobre o Próprio Corpo: a relevância da vontade na confirmação do seu regime, 5, FDUP, Coimbra, 2004: pp 53-213, 78 ss. e 196 ss.

${ }^{4}$ Do mesmo modo não será de retirar a natureza ao humano, enquanto realidade frente à qual se coloca, como sua complementaridade; dimensão real do que the é inteligível e inteligência pela qual pugno por sequela uma inevitável ética de responsabilidade. Fica assim a alteridade relacional complementada com a esfera da realidade sob o denominador da inteligência.
} 
então reivindicar normativamente a respectiva projecção. Daqui as gradações. É o «portal da dignidade (2). Depois, matizes distintivas entre o poder positivado da liberdade e de autodeterminação e as emanações concretas desse poder.

Sendo certo que a pessoa humana é plena de incompletudes e, por isso mesmo, surge permanentemente com necessidades por satisfazer (sobrevivência, cultura e comunicação), não deixo de lhe creditar respeito por um princípio de não ingerência. Por aqui segue também explicação para a alteridade. Existe um lio permanente de propostas e de aceitações para as interacções em que se arquitecta a comunidade. Tanto requer regulação e tutelas. Eis uma das facetas do estatuto da dignidade que explica o ser e o querer, livres enquanto respeitáveis. Respeito, um pleno de valor a impregnar legitimamente o ordenamento da realidade, com a vita activa da singularidade humana a exigir a conformação da condição humana. Ensejo de uma imortalidade ambicionada na eternidade do cosmos envolvente, para se afirmar enquanto homo faber: o manufactor e guardião do relógio. Uma humanidade que a partir do iluminismo do séc. XVIII se vai sofisticando em uma espiral tecnológica sem fim até que, questionada pela mensurabilidade da utilidade, sublima-se em afirmação, a um tempo da vida individual e da vida das espécies, e por aqui encontra nas cautelas com a saúde, digo eu para o que me traz, uma nova superação (3).

Mas se é assim, verdade é igualmente existirem contornos de delimitação dessa liberdade: imperativos que retraem uma absoluta individualização relevante da vontade. Problematizo: se adquiro evidente que frente à humanidade de uma mãe se desenvolve o respeito pela humanidade do recém-nascido - inquiro o reconhecimento do livre desenvolvimento de humanidade para o nascituro ${ }^{5}$, e a ambas se enfrenta a humanidade

\footnotetext{
${ }^{5}$ Constato que a ciência arranca reconhecimentos para os quais requer ao Direito soluções sui generis. É o caso dos pré-embriões: ex. da Ley de Investigación Biomédica espanhola (Ley 14/2007, de 03/07, BOE, 07/07/2007). O pré-embrião trata-se do embrião situado nos 14 dias após a concepção e integra o embrião gerado in vitro (art. $3, j$ ) e $s$ ), da Ley 14/2007) com controvérsia logo no seio doutrinário espanhol, vg. Nicolás Jouve de la Barreda: Aspectos biomédicos: estado actual de la investigación, Madrid, 08|05|2008, debate na Fundación Ciudadanía y Valores, acesso http://www.investigadoresyprofesionales.org/drupal/content/comentarios-la-ley-142007-de-investigacionesbiom\%C3\%A9dicas. Este Catedrático de Genética explica a distinção entre pré-embrião e o embrião propriamente dito- sendo este o que advém do desenvolvimento do ovócito fecundado no útero de uma mulher durante 2-8 semanas (56 dias), até que se inicia o período fetal. Todavia, aceitando as definições puramente biológicas, Barreda surpreende-se (perante a aparente contradição prevista nos arts. 33.1 e 35.a) e f) e suspeita da distinção servir para viabilizar intervenções de investigação científica, pois a definição de embrião generaliza-se no "desenvolvimento animal a partir do ovo fecundado" ou da «fertilização do ovócito", assim, Abercombie, Hickman, Johnson, Diccionario de Biologia, Labor. Barcelona, 1970; e Rieger,
} 
Michaelis, Green, Glossary of Genetics and Cytogenetics, Springer-Verlag, Berlim, 1976; Manuel Freitas e Costa, Dicionário de Termos Médicos, Porto Editora, 2005. Afirma ainda que esta legislação usa expressões que habilitam a concluir pela autorização da clonagem independentemente das finalidades. Certo é que a expressão «pré-embrião» consta na Legislação espanhola sobre «Técnicas de Reprodução Humana Assistida» desde 1988, e reformas posteriores, Ley 35/1988, 22/11; Ley 45/2003, de 21/11; e Ley 14/2006, $26 / 05$ em vigor. E tanto quanto se afigura, o «pré-embrião» não é predestinado para a investigação, já que sobre ele podem ser realizadas técnicas de diagnóstico genético pré-implantação (art. 2.․․ al. e) da LPMA portuguesa) destinadas a detectar insucessos no desenvolvimento embrionário precedentemente ao implante ou transplante uterino, Pedro Femenia López, Status Jurídico del Embrión Humano, con especial consideración al concebido in vitro, McGraw-Hill, Madrid, 1999, pp. 17 ss., Paula Martinho da Silva e Marta CostA, LPMA Anotada), Coimbra, 2011, p. 15; Yoeli Méndez López y Patricia Villamediana Monreal, Consideraciones bioéticas, biojurídicas y sociales sobre la aplicación del diagnóstico genético preimplantacional, in Revista de Obstetricia y Ginecologia de Venezuela, vol. 72, 2, 2012, pp. 115 ss., http://www.sogv.org/ROGV/ 2012Vol72N2.pdf\#page $=47$. Outra questão reside, evidentemente, na possibilidade de -mediante consentimento, art. 32.1 e 2 14/2007- existir prévia intenção em desviar préembriões para outras finalidades. Realçando a precisão terminológica da lei espanhola, Carlos Romeo Casabona, El Estatuto Jurídico del Embrión Humano, in Monografias Humanitas 4, Investigación con Células Troncales, Fundación Medicina y Humanidades Medicas, 2004, pp. 111-124, acessível em http://www.google.pt/url?sa=t\&rct=j\&q=\&esrc=s\&frm=1\&source=web\&cd=1\&cad=rja\&uact=8\&ved=0CCwQFjA A\&url=http\%3A\%2F\%2Fwww.fundacionmhm.org\%2Fpdf\%2Fmono4\%2FArticulos\%2Farticulo8.pdf\&ei=MnxC U9ezNaU0AWH84CgDw\&usg=AFQjCNGWKE-zC07kdq2f8RmINUWQGVGKSQ, onde afirma expressamente, quanto ao TC espanhol: «[Si en 1985 el TC sólo aventuró la negación al nasciturus de la titularidad del derecho fundamental a la vida, en 1996 y 1999 niega incluso la condición de persona -en sentido jurídico- al embrión in vitro]". Vislumbra-se a ectogénese (desenvolvimento embrionário e gestação tendencialmente integral de um ser em útero artificial, et pour cause, a par, peso os argumentos em favor da concessão de personalidade jurídica ao nascituro, sobre os quais aponto Stela Barbas, Direito do Genoma Humano, Almedina, 2007, pp. 235-247, onde me supro e dou vulto ao precioso rol bibliográfico e inteligentes considerações. Sem esgotar, Tiago Figo, Tutela Juscivilística da Vida Pré-Natal: O Conceito de Pessoa Revisitado, Coimbra, 2013, concretamente sobre o embrião não implantado, pp. 202-205, centra a sua tese em uma sábia premissa que recolhe em Paulo Mota Pinto, Os Direitos de Personalidade no Código Civil de Macau, BFDUC, LXXVI, Coimbra, 2000, p. 210: a de que a personalidade jurídica abarca os «modos de ser», de onde "o titular» exerce tutela (por si ou representado) até ao noli me tangere; pulando agora a questão da titularidade. Daqui retira argutamente a constatação de que o "...concebido já é uma realidade físicopsíquica e jurisgénica, pelo que deve ser centro de imputação dos direitos de personalidade adequados ao seu estatuto.», ID, ibid, pp. 106 ss. A questão merece muita atenção, pois pese a prudência da doutrina., e, claro, a controvérsia, afigura-se-me crescente na doutrina portuguesa a existência de patamares progressivamente comuns, onde parecem confluir e assestar progressiva assertividade ao progressivo reconhecimento das protecções típicas da esfera de personalidade ao humano concebido, vg: Oliveira Ascensão; Capelo de Sousa; Leite de Campos; Menezes Cordeiro; Bigotte Chorão; Pais de Vasconcelos; Carneiro da Frada; Paulo Otero; Teresa Lobo Xavier; Maria Clara Sottomayor; Gabriel Gonçalves; José Gonzalez; Lorena Brito; Simara Almeida; Helena Melo; Francisco Amaral; Henrique Mota. João Álvaro Dias elaborou catálogo premonitório dos problemas logo em 1996, subscrevendo cautelosamente Alonzo Perez: «[a vida embrionária é merecedora de respeito e da atribuição de uma personalidade jurídica que é absolutamente nuclear nos primeiros passos de um devir]", Procriação Assistida e Responsabilidade Médica, 21, BFDUC, Coimbra, 1996, pp. 204-218, maxime 211. No reduto da essencialidade do valor vida forçosamente reportado à concepção (independentemente dos planos que podem meramente justapor-se com diferentes graduações - ao sabor das fatias dos tempos - quanto à espessura de protecção em várias disciplinas: Constitucional, Penal, Civil), a doutrina propende esmagadoramente em a colocar axiologicamente sob alçada e protecção do ordenamento jurídico, sob diferentes densidades, claro está. Ana Paula Guimarães, Alguns Problemas Jurídico-Criminais da Procriação Medicamente Assistida, Coimbra, 1999, pp. 141 ss., pp. 147-168. Aqui, raros são os nomes, entre os maiores da doutrina referencial, que se afastam de um ponto de convergência, mas a opção demonstrativa, escolho-a entre outras felizes e oportunas -exactamente na controvérsia em que está inserida-, a de um voto de vencido de José Cardoso da Costa, que tomo em um sentido que generalizo como inerente à normatividade de um texto com natureza fundante não pode deixar de reflectir dever ser protegida a vida nascida ou por nascer, pois que a protecção 
dos agentes médicos; a humanidade da comunidade e assim por diante, pois parece-me vantajoso reconhecer que a dignidade advém do reconhecimento projectado nos demais seres e na própria natureza, não como mecanismo para se afirmar o ser humano, mas como meio para se reflectir em uma progressiva superação ${ }^{6}$. Em suma: uma só proposição para múltiplas expressões e orações. E logo se pressente a indeterminação da proposição humanidade, como parece ser a sua qualidade de incompletude em ensejo contínuo: axiomaticamente desvelada. São os apetites de uma inevitabilidade? O decisionismo ${ }^{7}$.

se concretiza «[ao mesmo título, já que da mesma vida se trata: daquela que se abre a um homem para a realização de um projecto e dum destino únicos e irrepetíveis, mas cuja potencialidade singular já se encontre inteira no próprio embrião]", in Ac. TC n. 25/84 (Rel. Joaquim Costa Aroso), acessível http://www.tribunalconstitucional.pt/ tc/acordaos/, e BMJ, 320, 1982, p. 224 ss. Trata-se de uma asserção que convive com os conflitos que assolam um legislador e uma jurisprudência constitucional nos processos de decisão em que opere uma concordância prática axiológica. Também Vera Lúcia Raposo, Direitos Reprodutivos, in Lex Medicinae, Ano 2, 3, 2005, p. 125 coloca a questão de forma lapidar, sobre o problema da "guarda de embriões»: "[só posso falar em guarda dos embriões (...) partindo do pressuposto de que os embriões já são vida humana, ainda que de uma forma diferente do ser humano já nascido. Caso contrário, terei de qualifica-los como coisas e, por conseguinte, questionar a quem deve ser atribuída a sua posse ou propriedade]». Em rigor, não considerar a inequívoca protecção da vida (intra-uterina), como bem absoluto, cabe uma primeira questão: como e onde o subjectivar senão no próprio? E se o próprio não o merecer em circunstância alguma então como ressarcir os danos sofridos pelo recém-nascido que foi objecto de ofensas durante a gravidez? Os danos verificaram-se em momento em que não possuía direito algum? São direitos da mãe? E se foi a mãe a responsável? Se em ninguém se subjectivar, então cabe ao Estado a protecção da vida intra-uterina, que sem conflitos entre bens jurídicos tuteláveis, não acarreta qualquer responsabilidade civil extracontratual? Pela negativa se circunscreve uma insustentabilidade leveza que desafia a revisitação ao nascimento completo com vida; aqui, Tiago Figo. A resposta que afasta o direito civil da personalização reclamada a um ser que se reconhece ser- mostra metaforicamente o que terá levado Daniel Defoe a retirar da absoluta solidão a personagem Robinson Crusoe. Em termos actuais parece impor-se à sombra da garantia de um livre desenvolvimento um ponto de partida casuístico que não securitário, mas em que a regra geral seja consentânea com a evidência de que o parto é um importante momento da vida humana, mas é na concepção que se verifica o componente primordial: a determinação meta-vontade.

6 Divergência com Francis Fukuyama, O Nosso Futuro Pós-Humano: consequências da revolução biotecnológica, Quetzal, Lisboa, 2002, pp. 220-226. Parece circunscrever o reduto diferencial da superioridade moral dos humanos, como via de compreensão e preparação do futuro. Creio que a questão se coloca diferentemente - forçando uma hierarquia de espécie, não deixa de implicar uma valoração, arriscando hierarquizar também outras diferenças dentro da espécie onde estas se esbatam por força de analogias: um ser humano em coma e um animal vivo, ambos para experimentação científica-, mas muito mais facilmente na composição diferenciada entre seres e nas respectivas coordenações da vulnerabilidade e soluções do que parece também comum: a dependência e os requisitos duma representação relacional inclusiva; neste sentido, Maclntyre, Dependent Rational Animals, pp. 3 ss., por todos, Fernando Araújo, $A$ Hora dos Direitos dos Animais, Almedina, Coimbra, 2003, pp. 340 ss..

${ }^{7}$ No que seja excludente da condição de homo sacer. 


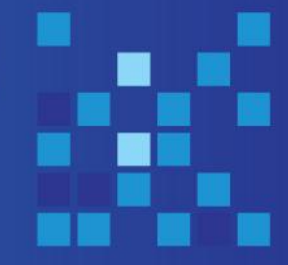

\section{A autonomia: radicalidade da recusa e liberdade de revogação}

No campo da saúde a manifestação relevante da vontade tem sido, como é consabido, objecto do estudo da doutrina do consentimento informado ${ }^{8}$ e esclarecido ${ }^{9}$. A via possui várias faixas e bermas: a actuação nos limites da prudência dos conhecimentos científicos; as cautelas com o foro privativo do necessitado, o registo, a documentação, a idiossincrática disponibilidade do candidato a uma intervenção, no que esta prepara o futuro. E será ainda de assumir todas as demais esferas da intenção de tratamento ou diagnóstico, de modelação, de reserva quanto à intimidade, de exposição às actuações cujo carácter técnico se aceitem além do estado recomendável da ciência, de cuidado, etc. Para o profissional de saúde não será, pois, indiferente arrumar-se igualmente em um alvedrio partilhado de permissibilidade. Mais precisamente, uma discricionariedade (enquanto critério decisório). Uma escolha de onde se deve poder retirar uma razão de ser, um discernimento. Proponho inserir aqui as variáveis do conceito de «discretion» a que Herbert Hart emprestou atenção para as actividades —como sejam juiz ou agente médico, digo eu- em que existe indeterminabilidade, seja normativa seja da realidade físico-

\footnotetext{
${ }^{8}$ Daniel Serrão prefere as expressões assentimento ou concordância, Bioética, Verbo, Lisboa, 1996, p. 79. Sobre divergentes significados conceptuais: o consentimento remetido para uma actuação justificante de uma invasão de esfera jurídica alheia e o assentimento como a presunção juridicamente assumida do pressuposto convivencial da beneficência médica (também judicial, vg.: nomeação obrigatória de um mandatário para a representação em juízo), por todos, Costa Andrade, Consentimento, Coimbra, 1991, passim.

${ }^{9} \mathrm{O}$ acento tónico no esclarecimento não é exclusivo da Escola de Coimbra; também a doutrina francesa e a alemã o preferem para a formação da vontade (João Loureiro, Constituição, I, p. 484), seja pelo rigor que transporta seja pela insistência na consecução da informação. Oferece-se-me falacioso obter simplesmente a declaração - mesmo sincera - de vontade sem uma efectiva prestação das informações prévias adequadas à compreensibilidade do homem comum_, mas sobretudo, sem a certificação dos mínimos de compreensão das informações: a questão em causa é substancial que não formal. Assim, Guilherme de Oliveira, Estrutura,Temas, pp. 67 ss; Orlando de Carvalho, Transplantações e Direitos das Pessoas, in AA. VV: Transplantações: colóquio Interdisciplinar, 25/03/93, CDB|FDUC, JNICT, 1993, p. 143; João Vaz Rodrigues, $O$ Consentimento Informado para o Acto Médico no Ordenamento Jurídico Português, CDB|FDUC, 3, Coimbra, 2001, p. 242 s.; André Dias Pereira, O Consentimento Informado na Relação Médico-Paciente: Estudo de Direito Civil, CDB|FDUC, 9, Coimbra, 2004, p. 209; sem esgotar, como homenagem a Mário Raposo, Consentimento Informado na Relação Médico-Doente, O Direito, 124, pp. 407413. Recordo o ensino de Orlando de Carvalho ao distinguir direito à informação de direito ao esclarecimento "só a este dando eventualmente primazia sobre a esfera privada e pessoal...», com as limitações sobre o segredo «próprio ou alheio» ID., Para uma Teoria da Pessoa Humana, TGDC,_p. 266, nota 69; e, a contrario sensu, dando ênfase à eventual irrelevância do consentimento prestado por quem possua dificuldades ad hoc de entendimento (les faibles), Stefano Rodotà, Le Droit face aux Dilemmes Moraux de la Vie et de la Mort: Présentation génerale des problèmes, in Actas do 20. Colóquio de Direito Europeu, Glasgow, 10-12 Setembro de 1990: Le Droit face aux Dilemmes Moraux Concernant la Vie et la Mort, Conselho da Europa, Strasbourg, 1992, p. 25 s. No Direito Penal, slesg, Costa Andrade, Consentimento, pp. 460 s, notas 292|293; Álvaro da Cunha Gomes Rodrigues, A Negligência Médica Hospitalar na Perspectiva Jurídico-Penal: Estudos sobre a responsabilidade criminal médico-hospitalar, Almedina, Coimbra, 2013, pp. 52 ss.
} 
psíquica. Hart ponderou a componente de actuação — de preenchimento do que se oferece como imprevisível- e que inclui a liberdade de actuação circunspecta, face a uma realidade carente de solução por opção conjecturável ${ }^{10}$. A «discretion» que serve os profissionais de saúde não é — da mesma sorte— indiferente aos pacientes, nem a quem os julgue. Todos se submetem a processos análogos ao procedimento de qualificação de facto e inserção em valores que ditam uma conduta resultante da escolha entre o que possua graus de indeterminação e que é ditado pelos valores assumidos (no caso do ensaio de Hart, face ao ditame das decisões de juridicidade). O respeito pela autonomia encontra esferas de compressão logo na ordem pública, no abuso de direito, na legítima defesa de terceiros ou na colisão de direitos, sem esgotar. $O$ alvedrio mais absoluto do paciente pode assim constituir mero impulso de capricho, mas deve suscitar nos outros uma apreciação sobre legítima discricionariedade. Como? Persistir em indagar sobre a razão de uma decisão implica a necessidade de a ordem social aquilatar justificações, exigindo-as consoante os valores correlacionados com aquela vontade. A questão da

\footnotetext{
${ }^{10}$ Herbert Hart, Discretion, in Harvard Law Review, 127, 2, Dezembro, 2003, pp. 652 ss. Trata-se de um curioso ensaio de 1956, em que permaneceu em Harvard como professor visitante, e que distribuiu para discussão e debate do então recente «Legal Philosophy Discussion Group». Debruçou-se sobre a necessidade de ponderar os mecanismos de escolha e respectiva fundamentação sobre alternativas válidas de actuação ou de manifestação da vontade ou de decisão. O alvedrio assenta em escolhas, cuja fundamentação assume, por necessidade de legitimação, autonomia para o processo de aferição ou de certificação. llustrando: numa festa opto por ingerir água, sumo ou vinho porque me apetece (arbítrio puro) ou por razões plausíveis: manter-me lúcido, excitar o cérebro ou passar uma determinada imagem. A expressão destas razões ou opções concludentes são evidentemente essenciais para compreender e discernir o processo de decisão. A primeira justificação encontra-se fora do âmbito do alvedrio partilhado, discricionário, para passar a arbítrio. Como afirma: «A discret person is not someone who just remains silent but who chooses to be silent when silence is called for». Por outro lado, as evidências absolutas excluem a necessidade da compreensão da escolha no processo de decisão (porque razão escolho uma faca de entre uma colher e um garfo para afiar um lápis). O que de extraordinário abrem estas páginas é a futura possibilidade de aceitação de um processo de adjudicação na racionalização legal do processo decisório com opções criativas de escolha. Exactamente um pomo fulcral da discórdia que alimentou a controvérsia com Ronald Dworkin (textos seleccionados por José de Sousa Brito, Filosofia do Direito e do Estado, AAFDL, Lisboa, 1981/82. De Hart, El Nuevo Desafio al Positivismo Jurídico, pp. 61-76; de Dworkin, The Model of Rules I -Taking Rights Seriously - pp. 115-146). O ensaio em causa circulou e foi debatido em Harvard, mas não foi desenvolvido pelo $A$. que não mais retomou estas ideias. Permaneceu inédito até que Geoffrey Shaw o colocou em estampa. Nicola Lacey, The Path Not Taken: H. L. A. Hart's Harvard Essay on Discretion, ibid, pp. 636 ss; Geoffrey Shaw, H. L. A. Hart's Lost Essay: Discretion and the Legal Process School, ibid, pp. 666 ss., HLR, 127, 2, December 2013. Neste último ensaio, Shaw sublinha dos diálogos reflexivos entre Herbert Hart e Henry Hart o eco deste a Fuller em Novembro de 1957, logo após a saída de Harvard: "[Discretion, it seems to me, envolves the act of choice between two or more alternatives... each of which is regardable as permissible. Adjudication envolves choice between two alternatives, one of wich is regarded as right...."». Eis a linha que conduzirá às contrapostas convocações de Dworkin: uma construção normativa proposta pela intermediação jurisprudencial inequívoca - juiz Hércules - assente no curso social de uma racionalidade razoável total, por oposição a uma referência normativa de reconhecimento à normação tendente à superação de uma inevitável indeterminação, proposta por Herbert Hart.
} 
opção passa desta forma a uma certificação da razoabilidade das premissas que a fundam. E estas podem escapar-se à esfera do que seja defensável permanecer em reduto das íntimas e secretas convicções: verdadeira riqueza do mundo interior, onde a protecção da liberdade e da autonomia se escudarão a prestar tributo, senão à divulgação, por certo à respectiva justificação ${ }^{11}$. A indagação pode resultar na contribuição do próprio ou em análise do quadro de facto ostensivo, mas até onde prosseguir? Exemplos? As recusas, vg: em saber.

\section{A protecção: génese disciplinar em revisão. Cuidado, vulnerabilidade e confiança.}

O esclarecimento e o respeito pela autonomia do paciente perpassam, aglutinam e regulam a actividade médico-medicamentosa e adjacentes terrenos de investigação, nesse estatuto inalienável, indissociável, absoluto e ilimitado da personalidade humana em que radicam, como saldo, os poderes/deveres de cuidar. Situam-se entre o regime tendencial de protecção negativa (obrigação determinável decorrente do respeito exigível adentro da liberdade) e os poderes deveres decorrentes da (des)inibição de interpenetração em esfera alheia, sobretudo em vista dos deveres gerais de auxílio, fundados na solidariedade ${ }^{12}$, i.é., afinando rigores, desabrocham os deveres de cuidado ${ }^{13}$. O cuidado exerce-se para

\footnotetext{
${ }^{11}$ E para esta, deixando por ora a pertinácia da decisão -inquirida, não se evidencia sempre correctasobram dois outros passos: a satisfação das questões de facto condicionantes intermediariamente intelectivas, onde nenhuma outra se imponha apurar, e que o raciocínio assim formado pelas inferências intelectivas satisfaçam a conclusão questionada, de sorte a que uma mente familiarizada com aquela situação concreta não logre promover uma qualquer condição suplementar —uma questão pertinazsusceptível de abalar o que sejam as convicções individuais de uma opção em uma esfera onde se impõe o respeito. Neste procedimento encontro o preenchimento do que se oferece indeterminável em um processo de decisão, perto de Bernard Lonergan, Insight - Estudio Sobre La Compreensión Humana, Sígueme, 37, Salamanca, 2..$^{-}$, 2004, pp. 347-352.

${ }^{12}$ Emprego solidariedade restritamente, com o sentido etimológico que André Compte-Sponville lhe dá de se "pertencer a um conjunto in solido, como se dizia em latim, isto é, "para o todo"» como "fato de uma coesão, de uma interdependência, de uma comunidade de interesses ou de destino", como um alicerce inevitável para o consequente. Reconheço que a solidariedade, como virtude, pode, sem mais onde se revele, valer o que podem valer os interesses: pouco ou nada por si só. Ou a comunidade é real e efectiva, e a defesa de outrem se reduz por força a uma defesa própria (sem retirar potencial valia à realidade: estou convencido de que são tão solidários os soldados do exército invasor como os do invadido) ou como ideal de comunidade: os esforços em prol do outro passam a ser justiça ou generosidade, consoante a certificação da densidade ética em causa. Pois assim se compreende que o léxico político use a expressão solidariedade quando pretende justificar as intervenções militares internacionais ou as campanhas de distribuições de géneros, medicamentos, etc. Continuando perto, quando se é solidário com os carenciados o que ocorre em rigor é servir a justiça ou ser generoso, e estas são as virtudes que incorporam aquele estado de facto, Pequeno Tratado das Grandes Virtudes, Martins Fontes, São Paulo, 2002, pp. 98-101.

${ }^{13}$ Sobre a matéria dos cuidados e da construção de uma nova ética em seu torno, João Loureiro, Saúde no fim da vida: entre o amor, o saber, e o direito. II - Cuidado(s), Revista Portuguesa de Bioética, 4, Abril-Maio,
} 
impedir a eventualidade de dano, próprio ou alheio. É comportamento de respeito cautelar pelo neminem laedere ${ }^{14}$. Para tanto, Guilherme de Oliveira reabilitou aturadamente no seu ensino a referência fundamental de um princípio de confiança ${ }^{15}$. Aqui se estriba o animus do que será a reivindicada autonomia da disciplina do Direito da Medicina ${ }^{16}$, em cuja fattispecie normativa avultam a hospitalidade do exercício da Medicina (Faria Costa) com as referências de respeito e de solidariedade que tutelem os direitos e fundamentalmente os deveres recíprocos emergentes da relação (jurídica) de cuidado e de perigo, entre profissionais de saúde e os beneficiários dos cuidados daqueles.

Existe uma questão prévia sobre se as normas e os diplomas que, em retalho, vão merecendo a tarefa de compilação, se mostram viáveis na sua dispersão para a compreensão destas matérias ${ }^{17}$. O mesmo é dizer, se existe um Direito da Medicina a ser autonomizado com características e necessidades específicas ou se estamos perante uma «autonomia sectorial» que se ergue, identificável, de várias disciplinas como sejam: o Direito Internacional, Constitucional, Penal, Administrativo, Civil, etc., de onde as questões sobre o exercício da actividade da medicina são objecto de relances e análises elaboradas

pp. 37-83, com indicação bibliográfica preciosa, e, ID, Constituição, p. 49, onde relaciona a tentativa de superação da fragilidade do ser humano exactamente enquanto um dos factores da exposição relacional com os demais. Também José de Faria Costa, O Perigo em Direito Penal, Coimbra, 1992, pp. 400 ss., nota 89. Igualmente André Dias Pereira, Direitos dos Pacientes e Responsabilidade Médica, Coimbra, 2012, pp. 32, 47 (notícia do Ac. Supremo Tribunal Federal alemão que justamente co-atribui ao cuidado uma qualificação da relação médica a transcender a relação jurídica contratual), 50, 58 (nota 124), 99 ss., 131 ss. (deveres do médico) 167 ss., 325 ss., 333 (nota 927: dever de cuidado do paciente), 360, 497, 590, 615 ss. 665, 673, 677, 717, 783 ss. A pretexto, integrando a empatia no âmbito inter-relacional dos cuidados de saúde, Mohammadreza Hojat, Emphaty in Patient Care: Antecedents, Development, Measurement, and Outcomes, Springer, 2007, pp. 120 ss., com homenagem ao recorte do conceito por Howard Spiro, desde meados 1980. Como contraponto entre terapia, cuidados aos limites da agonia —tempo a exigir reflexão—, eutanásia e o aprofundamento dos cuidados paliativos, Sergio Cecchetto, Curar o Cuidar: Bioética en el confin de la vida humana, AdHoc, Buenos Aires, 1999, pp. 82-93 e 131 ss.

${ }^{14}$ Penso nas subtis distinções entre as várias matizes da obrigação geral de respeito e de obrigação passiva universal, tal como nas cambiantes sobre a obrigação neminem laedere (e abuso de direito) que Orlando de Carvalho ensina, Direito das Coisas: Do Direito das Coisas em Geral, Centelha, Coimbra, 1977, pp. 120-133.

${ }^{15}$ Além das aulas e intervenções, CDB|FDUC, ID, Temas: Estrutura Jurídica, pp. 66 ss; Fim da Arte, pp. 99 ss.

${ }^{16}$ André Dias Pereira, Direitos, pp. 49 ss; 61-70; 777-779.

${ }^{17}$ Colectâneas legislativas portuguesas: Direito da Medicina. Álvaro Dias, Colectânea de Legislação Médica, I-II, Almedina, Coimbra, 2002; Helena Moniz (colab/Carla Barbosa), Legislação de Direito da Medicina, Coimbra, 2008; Manuel Curado, Direito BioMédico: Colectânea de Legislação e Outros Documentos, Quid Juris, 2008; Direito da Medicina: Legislação Consolidada, Jurisprudência e Pareceres, 2014, INCM. A par: relevantes publicações sobre legislação avulsa comentada: Paula Martinho da Silva, CDHBio-anotada, Cosmos, 1997; João Loureiro, Protocolo Adicional - Comentários Finais, pp. 171-203, nota 2, pp. 172-175, in AA.VV. (org.Walter Osswald: Instituto de Bioética, Universidade Católica, Porto), Direitos do Homem e Biomedicina: Actas da Oficina sobre a Convenção para a Protecção do Homem e da Dignidade do Ser Humano face às Aplicações da Biologia e da Medicina, UC, 2003. 
de uma «forma mais ou menos desligada e paralela» ${ }^{18}$, i.e., por confronto entre ópticas integradoras ou meramente sectoriais do direito da medicina. Pugnando por uma perspectiva integradora ${ }^{19}$ situam-se Albin Eser que, vg, extrai o regime da procriação medicamente assistida do Direito da Família ou Carlos Casabona.

\section{A dignidade deriva em respeito: um feixe aglutinador de protecções}

O feixe de direitos e de deveres que integram uma relação jurídica médicomedicamentosa recebe enfoque especial no paciente, na prossecução dos respectivos interesses em saúde, e, para tanto, na respectiva protecção dos direitos especiais de personalidade. Da essencialidade da dignidade resulta o respeito e explica-se a genética liberdade individualizante e a protecção da integridade físico-psíquica ${ }^{20}$. Raiz e tronco que relacionam o exercício da liberdade de vontade ${ }^{21}$ (preponderantemente na vertente da autodeterminação), a par do aludido poder de respeito que em matéria de dogmática

\footnotetext{
${ }^{18}$ Albin Eser, Perspectivas do Direito da Medicina, RPCC, 14, 2004, pp. 11-63.

${ }^{19}$ Sigo de perto João Loureiro, Filho(s) de um Gâmeta Menor?, p. 16, nota 85 (cita Carlos Romeo Casabona: El derecho Medico: su evolución en España, in ID: Derecho biomédico y bioético, Granada, 1998, pp. 1-3; 1 28).

${ }^{20}$ Parece convir enunciativamente com um estado inato de recusa sobre qualquer intervenção Manuel Silvério Marques, O Espelho Declinado, Colibri, Lisboa, 1999, pp. 34 s; 144 ss (pelo lado da actividade médica). Assim estudo Orlando de Carvalho e Carlos Mota Pinto, para quem o consentimento requerido às intervenções médicas em benefício da própria saúde ou da de terceiros é tido como «uma limitação voluntária do direito à integridade física», ID, TGDC, pp. 211 ss. Leio em Guilherme de Oliveira: "O dever de obter o consentimento informado funda-se no direito à integridade física e moral de cada indivíduo" (Prática, Temas, p. 165), de onde resulta o respeito do agente médico «pelo direito autónomo do doente à livre determinação em matéria de saúde», O Fim da Arte Silenciosa, p. 103.

${ }^{21}$ Orlando de Carvalho, Sumários, pp. 94 ss, individualiza no consentimento esclarecido o direito à liberdade (a posicionar-se à cabeça dos vários direitos ou bens de personalidade na hierarquia que o legislador deveria estabelecer). Afirma a propósito para o campo penal: — «Não havendo 'consentimento do paciente' haverá violação, não do direito à integridade física, mas da liberdade de vontade (...)", permitindo discernir o sentido invocado da dupla e conexa existência daqueles direitos especiais de personalidade: - «[Ao invés do que penalmente se dispõe, a falta de consentimento determina sempre, no campo civil, lesão do direito à integridade física, mesmo que se preencham os requisitos do art. $150 .{ }^{\circ}$ do Código Penal. Se o corpo ou a saúde é que são objecto da agressão, o direito à integridade física está obviamente em causa. Dir-se-á que, sendo respeitadas as leges artis, etc., não há danos mas proveitos. No entanto, como se compreende, o dano não é aqui a alteração para pior da situação físico-psíquica: é a intervenção não consentida na zona de reserva que o corpo é para a pessoa, é a lesão da incolumidade (noli me tangere) do corpo alheio. Juiz do bem e do mal para o seu corpo é a própria pessoa - não é outra pessoa, mesmo que qualificada e bemintencionada. Decerto que, se a saúde não piorou, mas melhorou, o dano parece reduzir-se apenas à falta de consentimento e, logo, à simples lesão da liberdade de vontade. Sabe-se, contudo, que uma intervenção, ainda que bem-sucedida, provoca sempre incómodos físico-psíquicos que, se assumem o mínimo de relevo para o Direito, não podem não haver-se como lesões da integridade físico-psíquica da pessoa]». A disciplina penal é especialíssima e determina originalidades. Em síntese, será de arredar a qualificação como crime contra a integridade física das intervenções médico-medicamentosas respeitando as leges artis e com intenção terapêutica, como decorre da solução portuguesa, art. $152 .^{\circ}$ do CP.
} 
civilística urge ser integrado no patamar superior que merece. É que o dever de respeito explica a dignidade e todas as suas emanações de liberdade, de integridade, de autonomia, autodeterminação, etc. No fundo e sem ingenuidade, o respeito constitui um dos portos fulcrais onde se verificam a partida e a chegada do que se seja ser humano. É certo que a viagem se fará entre as várias opções possíveis que se vão colocando ao longo do curso da via-vida e que nos desafiam as decisões para que estamos vocacionados, isto é, para agir. Agir, ponderando a nossa «neotenia», a nossa característica de permanente tentativa de superação sobe a impreparação crónica a que estamos votados, como ensina Savater. Em síntese, e para transes mais difíceis, ripostou Erasmo de Roterdão a quem o acicatou a optar entre o Papa de Roma e Lutero: «não navega mal quem passa a igual distância de dois males diferentes ${ }^{22}$

Em rigor, uma análise lógica sobre a autonomia pode (deve) ser ampliada como vector relacional axiologicamente ímpar para a compreensão do aparente paradoxo entre a individuação e as recíprocas pontes entre cada ser humano e o outro tal como as que se estabelecem necessariamente nas comunidades onde interage, onde vive. É que as realidades cerceiam-se e completam-se; limitam-se, comprimem-se, facultando prioridades em vista de um determinando casuísmo, para se realizarem, e, até, para poderem expandir-se ${ }^{23}$. O ser humano, ainda egoisticamente perspectivado, projecta-se logo em

\footnotetext{
22 Savater, A Coragem, pp. 25 e 15. Mesmo sentido, Aristóteles, Ética a Nicómaco, Livro II, Cap. XVIII e XIX, 1108b11 1 1109b28, Livro V, Cap. IV, 1131b25-1132b20, pp. 56-58, 114 ss.

${ }^{23}$ Ponderando a Teoria das Esferas (Hubmann e Henkel), reconhecida pelo TC Alemão e pela riquíssima jurisprudência do TEDH, existe extenso rol no laboratório de uma jurisprudência que desenha a esfera privada (onde incluo a íntima e a individual; a de intimidade confidencial e segredo, consoante os conceitos dos AA.). Âmbito do art. 8. CEDH, cf. «guia prático sobre a admissibilidade», http://www.echr.coe.int/ (Case Law-case law information-Admissibility guide) e em http://www.gddc.pt/ pp. 82-86. Quanto ao conceito de esfera da "vida privada" afasto definições, mas vislumbram-se jurisprudencialmente as estremas de uma noção relevante para o direito comum Europeu: esforço notável de «linguagem universal», assim: Niemietz $v$. Alemanha, § 29; dando noção amplíssima (Peck v. Reino Unido, § 57; § 61), com os elementos seguintes: integridade física e psicológica ou moral de uma pessoa ( $X$ e $Y$ v. Países- Baixos, $\S 22$ ), incluindo o tratamento médico e exames psiquiátricos (Glass v. Reino-Unido, §§ 70-72; Y.F. v. Turquia, § 33, exame ginecológico forçado; Matter v. Eslováquia, § 64; Worwa v. Polónia, § 80), saúde mental (Bensaid v. ReinoUnido, § 47); integridade física das grávidas (aborto) (Tysiac v. Polónia, § 107 e 110, e $A$ B e C v. Irlanda[GC], § 244-246); integridade físico-psíquica das vítimas de violência doméstica (Hajduová $v$. Eslováquia, § 46); identidade física e social (vg, o direito a obter informações sobre as origens: identidade dos progenitores) (Mikulic v. Croácia, § 53; Odièvre v. França [GC], § 29); apreensão de documentos de identidade (Smirnova v. Rússia, § 95-97); nome e apelido (Mentzen v. Letónia); Burghartz v. Suiça, § 24; Guillot v. França, § 21-22; Güzel Erdagöz v. Turquia, § 43; Losonci Rose e Rose v. Suíça, § 26; estado civil: parte integrante da identidade pessoal e social (Dadouch $v$. Malta, $\S 48$ ); relações do pai com o filho presumido, vg para impugnação da paternidade (Rasmussen v. Dinamarca, § 33 Yildirim v. Áustria); direito à imagem (Von Hannover v. Alemanha, § 50-53; Sciacca v. Itália, § 29; Reklos e Davourlis v. Grécia, § 40); reputação (Chauvy e outros v. França, § 70; Pfeifer v. Áustria, § 35; Petrina v. Roménia, § 28; Polanco Torres
} 
desígnios de inclusão, de desejada inserção nos círculos da comunidade onde se pretende desenvolver plenamente, onde se afirma. Basta a mera intuição para fornecer a autoridade necessária à afirmação verdadeira de um desejo de ser desejado, de ser reconhecido, pelos que vivem em redor. Este é um valor que não pode ser desprezado em sede de livre

e Movilla Polanco v. Espanha, § 40) honra (A. v. Noruega, § 64); identidade de género (B. v. França, § 43 a 63), reconhecimento jurídico de transexuais operados (Christine Goodwin v. Reino Unido [GC], § 77); orientação sexual (Dudgeon v. Reino Unido, § 41); vida sexual (ibidem, Laskey, Jaggard e Brown v. ReinoUnido, § 36; A.D.T. v. Reino-Unido, § 21-26); estabelecer e manter relações com os semelhantes e mundo exterior (Niemietz v. Alemanha, § 299; laços sociais entre imigrantes e a comunidade onde vivem (Üner $v$. Países- Baixos [GC], § 59); relações afectivas entre pessoas do mesmo sexo (Mata Estevez v. Espanha (dec.); desenvolvimento e autonomia (Pretty v. Reino- Unido, $\S 61$ e 67, fim de vida indigno e penoso (Haas v. Suíça, § 51); respeito pelas decisões de ser pai ou mãe (Evans v. Reino-Unido[GC], § 71), escolha das circunstâncias nas quais uma pessoa torna-se mãe ou pai (Ternovszky v. Hungria*, $\S 22$, sobre um parto em casa). Aplicação do art. 8. ${ }^{\circ}$ ao direito de adoptar: adopção por pessoa solteira (E.B. v. França[GC], §46 e 49; acesso à adopção, Schwizgebel v. Suiça, § 73). A Convenção não garante ao asoptante o direito de pôr fim a esta adopção (Gotia v. Roménia); actividades profissionais|comerciais (Niemietz v. Alemanha, § 29; Halford v. Reino-Unido, § 44; Özpinar v. Turquia, § 46): restrições de acesso laboral (Sidabras e Dziautas v. Lituânia, $\S$ 47-50; Bigaeva v. Grécia, § 22-25); perfis de DNA, amostras celulares e impressões digitais (S. e Marper v. Reino-Unido[GC],§ 68-86); ficheiro judicial de infractores sexuais (Gardel v. França, § 58)); informaccões relativas à saúde de uma pessoa vg. seropositividade, Z. v. Finlândia, § 71; e C.C. v. Espanha, § 33, informações sobre capacidades reprodutoras, K.H. e outros v. Eslováquia, $\S 44$, informações sobre riscos para a saúde (McGinley e Egan v. Reino-Unido, § 97; Guerra e outros v. Itália, § 60); identidade étnica (S. e Marper v. Reino-Unido [GC], § 66; Ciubotaru v. Moldova*, § 53), direito dos membros de minoria nacional de conservarem a identidade, vida privada, familiar, conforme tradições (Chapman v. Reino-Unido [GC], § 73); informações sobre convicções religiosas e filosóficas (Folgero e outros v. Noruega [GC], § 98); pessoas com deficiência: aplicabilidade do art. 8. à obrigação de pessoa declarada incapaz de pagar a taxa de isenção serviço militar (Glor v. Suiça, § 54), mas não ao direito do deficiente aceder à praia durante férias (Botta $v$. Itália, § 35). Quanto ao respeito da vida privada, referencio: buscas e apreensões (McLeod v. Reino-Unido, § 36; Funke v. França, § 48); interpelação e revista de pessoa na via pública (Gillan e Quinton v. Reino Unido, $\S$ 61-65); vigilância das comunicações e conversas telefónicas: (Halford v. Reino- Unido, § 44; Weber e Saravia v. Alemanha (dec.), § 76-79); recurso a agentes infiltrados (Lüdi v. Suiça, § 40); videovigilância em lugares públicos/divulgação (Peck v. Reino-Unido, § 57-639; vigilância: utilização de GPS; tratamento e uso dos dados (Uzun v. Alemanha, §52); videovigilância laboral (Köpke v. Alemanha (dec.); caixa de supermercado suspeita de furto; ofensas ao meio ambiente: bem-estar individual e protecção do domicilio, vida privada e familiar (López Ostra v. Espanha, § 51; Tatar v. Roménia, § 97), cheiros de lixeira que afectam a cela de recluso: "espaço de vida" (Branduse v. Roménia, § 64-67), ruído (Deés v. Hungria* § 21-24, ruído da circulação rodoviária; Mileva e outros v. Bulgária, § 97; ruído em prédio. Questões relativas aos cadáveres (aplicabilidade do artigo 8..: indefinição sobre noção de vida privada ou de vida familiar: atraso na restituição do corpo de criança à família após autópsia (Pannullo e Forte v. França, § 36); recusa em autorizar transferência de urna (Elli Poluhas Dödsbo v. Suécia, § 24); direito de assistir ao enterro do filho nado-morto, cerimónia e funeral (Hadri-Vionnet $v$. Suíça, § 52); proibição do aborto: razões de saúde e bem estar - 0 artigo 8. não inclui direito ao aborto $(A, B$ e $C$ v. Irlanda, $\S 214$ e 216); recusa arbitrária da concessão da nacionalidade em certas condições, embora o direito de adquirir uma nacionalidade não esteja garantido, enquanto tal, na Convenção (Karassev e família v. Finlândia (dec.). $\underline{O}$ art. 8. ․ garante uma esfera individual de livre desenvolvimento da personalidade (Brüggemann e Scheuten v. Alemanha § 55), que não se confina às medidas que atingem a pessoa no seu domicílio ou locais privados: existem zonas de interacção entre 0 indivíduo e outros, mesmo em contexto público, que relevam privacidade (P.G. e J.H. v. Reino-Unido, § 56 e 57). Os actos prejudiciais à integridade físico-psíquica pessoal não implicam necessariamente ofensa ao respeito pela vida privada. Todavia, um tratamento cuja gravidade é desatendida no âmbito do artigo 3.ำ pode abrigar-se no artigo $8 . .-\mathrm{em}$ aspectos da vida privada, verificando-se efeitos prejudiciais da integridade física e moral (Costello-Roberts v. Reino-Unido, § 36). Pode haver situações sob alçada do art. 8. (detenção) que não alcançam a gravidade exigida pelo artigo 3.ำ (Raninen v. Finlândia, § 63).» 
desenvolvimento da personalidade. Daqui que a identificação individual pressuponha a respeito de um assentimento onto-axiológico do ser humano para que se realize a (inter)penetração genética da alteridade que é vocação humana. E no âmbito das actividades médicas, se assim é em termos tendencialmente individuais não posso deixar de considerar como prius a objectiva solidariedade humana e o decantado dever de actuação médico-medicamentosa de auxílio. Daqui decorre uma obrigatoriedade jurídica que fundamenta várias estatuições de actuação para os agentes médicos. A sua técnica inclui o esclarecimento seja para a formação da vontade seja para o exercício permanente da reintegração do estado físico psíquico prévio em que redunda a saúde. Integra as leges artis, e em relação concreta, domina as leges artis ad hoc.

$E$, uma vez que incidem sobre o ser humano, onde a singularidade não pode deixar de ser tida em conta, quer o estado natural primevo de recusa perante o que-quer-queseja, quer as actuações de vontade posteriores (com eventuais recusas ulteriores), afiguram-se como meio fulcral, pois a respectiva ausência deixa as instituições e sobretudo os demais a persistirem no respectivo carinho pela solidariedade, com os correspondentes agentes em dever de actuação, dever de auxílio. É potência que se visualiza na constelação universal da comunidade organizada. Mas, repito, o estado natural individual, a realidade genética é a recusa: noli me tangere.

\section{O que perpassa entre as disciplinas jurídicas}

Eis com simplicidade —necessidade de remoer e burilar — os elementos da equação clássica sobre as abordagens à protecção ínsita da dignidade e ao dever de respeito, na esfera da autodeterminação ${ }^{24}$ : o profissional de saúde encontra-se vinculado a viabilizar a tentativa da obtenção de condições-físicas prévias — quer as desejadas, quer as desejáveis que se situem em terrenos admissíveis-, mediante actuações aceitáveis a produzir na esfera de outrem que as merece, seja por necessidade, seja por vontade; e é exactamente aqui que se situa a segunda vinculação: para agir carece de ultrapassar o

\footnotetext{
24 No âmbito do Direito Constitucional português, o princípio da autonomia está profundamente correlacionado com o da dignidade e, como ensina João Loureiro, Constituição, I., pp. 474-487: «[Apesar de não ser um princípio fundante, a autonomia afirma-se como dimensão estruturante da bioconstituição, compreendendo várias dimensões que tomam a sério a matriz convivencionalista do direito e não desconhecem os olhos da relação médica nem todos os outros afectados quando está em causa o bem saúde]», p. 487.
} 
repúdio alheio e de aí permanecer com a sua aquiescência, i.e., sem que uma outra recusa reapareça. Necessita, pois, de que a sua actuação receba as manifestações de vontade concordantes para as opções e que assim se mantenham durante toda a actuação. Serve por ora sublinhar que o procedimento que aglutina os diversos requisitos que se posicionam para a manifestação de vontades(s) relevante(s) em uma relação tutelada pelo direito da medicina revelam uma relação altamente dúctil. E sobretudo que, em regra e por regra, só o momento da irreversibilidade da acção cristaliza a superação da recusa.

Os dois vínculos (o individual e o médico) convivem permanentemente? Não! Existem excepções e as suas presunções. Se a pessoa carente de intervenção estiver fora das condições da manifestação da vontade o agente actuará segundo a configuração possível que faça sobre a vontade alheia (primeiro patamar), ou segundo a sua própria configuração, por analogia comportamental objectivável caso nenhum indício possua da vontade do outro a conformar a sua perspectiva (segundo patamar). Poderá acontecer existirem silêncios conflituantes... Aqui só mediante uma configuração positiva, em termos legais, permitirá actuar (terceiro patamar), pois então teremos as apelidadas «soluções de dissentimento»: uma segunda presunção virtual contra a presunção natural individual, assente aquela em protecções universais de saúde que sacrificam a liberdade e o respeito individual.

Duas presunções portanto. A indicação que promana do silêncio assenta em uma resposta social de auxílio que vincula o agente médico, dando presunção suficiente para actuação. Ao invés, e simplisticamente: existindo indicação da vontade, é esta que se impõe e arrepia a bondade das outras, naturais, mas contraditórias (a que provém do ser humano consciente, com vontade válida é a presunção de recusa; a intenção da comunidade é a da acção beneficente). Compreende-se assim que um acidentado receba uma série de actuações agressivas para terapia ou que uma criança receba os melhores tratamentos disponíveis contra a expressa manifestação da vontade dos seus representantes legais (ou que desoriente o agente médico que lhe reconheça discernimento e bom senso possível, em uma vontade contraditória alternativa entre a que sugere, a que os representantes legais pretendem e a que o quadro de facto melhor propicia e o saber médico aponta para solucionar a maleita). A compressão social transcende hipoteticamente o desígnio individual perante o qual tem de aguardar sempre que para este seja viável pronunciar-se. 
O ser humano capaz está, deste modo, vinculado a manifestar uma vontade relevante caso se encontre em um quadro de necessidade e em condições para a manifestar. A vinculação a que o agente médico está adstrito é a de persuadir o paciente a que permita uma actuação na medida técnica proporcional e ou adequada a descortinar, solucionar ou atenuar os efeitos perversos dos padecimentos.

Este é um quadro de facto em que o Direito se move com alguma facilidade e aponta caminhos aparentemente seguros e afirmativos aos profissionais de saúde. Mas as tintas e as telas rapidamente oferecem matizes diversas para a Medicina e dificuldades que não permitem sair de um enredo cujo emaranhado se sofistica tanto quanto se procura simplificar. A pergunta seguinte, fulcral, é representativa do que acabo de afirmar: em uma situação limite de necessidade sem existência absoluta (ou relativa) de vontade actual do paciente, está o agente médico igualmente vinculado em permanecer vinculado à notícia da decisão anteriormente manifestada? Ou uma variante, em termos mais amplos matéria das directivas antecipadas-, deve o profissional de saúde actuar previamente no sentido de conjecturar e conformar a sua actuação consequente? Estes são problemas do quotidiano da vida dos profissionais de saúde.

Em caso de resposta afirmativa, as boas práticas de actuação dos profissionais de saúde incluem um esclarecimento recíproco dos agentes sobre a indagação das vontades, também recíprocas, e das opções possíveis disponíveis. Mais ou menos rapidamente, assim é. Assim parece ser também inequívoco que o reduto da liberdade individual é destacável da esfera de integridade físico-psíquica, onde razoável e necessariamente reside. Exigem ambos o respeito para fornirem a liberdade; a questão é a do exercício desta liberdade implicar singelamente a manutenção da vida ${ }^{25}$ ou a de impedir a actuação

\footnotetext{
$\left({ }^{25}\right)$ Exemplo clássico na jurisprudência americana é Bartling v. Superior Court (Glendale Adventist Medical Center), 1984. vol. 163; Cal. App. 3d 186 [209 Cal. Rptr. 220]. Anotações de Hastings, Feinerman e Ashby, em:

http://law.justia.com/cases/california/calapp3d/163/186.html. O caso opôs William Bartling e mulher contra o Hospital Glendale Adventist e médicos, por encarniçamento terapêutico. Os AA queriam desligar o ventilador de suporte. A decisão judicial foi proferida já após decesso. William deixou directivas antecipadas (designou a mulher como procurador de saúde) negando intubação e manutenção artificial da vida. $O$ hospital desatendeu, considerando existirem indícios de vontade infirme. O paciente, 70 anos, estava em estado terminal. O caso mereceu o exercício de «discretion». Neste aspecto, seria discutível rever precedentes ao abrigo da «mootness doctrine», i.e.: «[a principle of judicial procedure whereby American courts will not decide moot cases, that is, cases in which there is no longer any actual controversy. The inability of the federal judiciary to review moot cases derives from the requirement of U.S. Const. art. III, under which the exercise of judicial power depends upon the existence of a case or controversy. Therefore the courts will not hear or decide a case unless it includes an issue that is not considered moot because it involves the public
} 
perante uma crise que se supõe letal. Se a primeira questão ainda suscita controvérsia, a segunda constituirá seguramente causa de muita conturbação, especialmente no oxigénio médico.

Um exemplo simples pode ser construído com variáveis, mas redunda no seguinte: A e $B$, com percursos de comunhão de convicções e de sentimentos, capazes, afirmam simultaneamente em pleno domínio das suas faculdades, que não desejam a ministração de sangue ou de um procedimento para o caso de lhes sobrevir uma eventualidade. Perante a necessidade, $A$, consciente, altera a sua opinião no sentido do conselho médico, ao passo que B está inconsciente. A proximidade entre ambos leva A. a opinar que B. poderia perfeitamente alterar a sua opinião movido até pela sintonia sentimental com aquele... Por banda da equipa de profissionais de saúde existem igualmente agentes com dimensões éticas diferentes que têm de se entender, como servem de exemplo o anestesista, o cirurgião e o enfermeiro, etc. Os motivos que subjazem à liberdade podem ser os mais variadas, de comum, porém, avultam os de cariz religioso. Aceitar a determinação de vontade é a solução jurídica, mas será a médica? De todos os profissionais de saúde envolvidos? E perante a iminência de um desfecho fatal às mãos de um agente, perante a possibilidade de o paciente ter ganho de causa não ponderará aquele enviar às malvas a decisão deste, em que não se reconhece, do que dar bilhete de embarque aos infernos uma alma que pode não vir a ser penada? O que procuro indagar neste aspecto, especialmente quanto ao paciente, mas não só ${ }^{26}$, cabe perfeitamente na ilustração que Montesquieu escreve no prefácio ao seu Espírito das Leis:

Je me croirais le plus heureux des mortels, si je pouvais faire que les hommes pussent se guérir de leurs préjugés. J'appelle ici préjugés non pas ce qui fait qu'on ignore de certaines choses, mais ce qui fait qu'on s'ignore soi-même. / (...) L'homme, cet être flexible, se pliant dans la société aux pensées et aux impressions des autres, est également capable de connaitre sa propre nature lorsqu'on la lui montre, et d'en perdre jusqu'au sentiment lorsqu'on la lui dérobe.. ${ }^{27}$

\footnotetext{
interest or constitutional questions]", http://definitions.uslegal.com $/ \mathrm{m} / \mathrm{mootness-doctrine.} \mathrm{Os} \mathrm{casos} \mathrm{em}$ referência terão sido: Daly v. Superior Court (1977) 19 Cal. 3d 132, 141 [137 Cal.Rptr. 14, 560 P.2d 1193].) "[The novel medical, legal and ethical issues presented in this case are no doubt capable of repetition and therefore should not be ignored by relying on the mootness doctrine. This requires us to set forth a framework in which both the medical and legal professions can deal with similar situations]" (Dority v. Superior Court (1983) 145 Cal. App. 3d 273, 276 [193 Cal. Rptr. 288]).

${ }^{26}$ Posso perfeitamente incluir os profissionais de saúde, etc.

${ }^{27}$ Montesquieu, De l'Esprit des Lois, I, (Robert Derathé), Garnier Fréres, 1973, prefácio, p. 6.
} 
Há que interpretar a terrível maleabilidade dos apetites humanos, a cindir a vontade no que abandone as decisões, retirando-Ihes substância e crie naturais suspeições. São terríveis questões as que as modificações dos quadros de facto provocam em um ser humano e vice-versa. Será também opinião de Hannah Arendt ${ }^{28}$ quando cogita em torno das flutuações de alma. E o que é descrito em contextos sobre a desorientação da modernidade (e pós-modernidade) muito especialmente sobre a (re)localização dos conceitos de Estado-nação ${ }^{29}$ e refundação da universalidade tem igual impacto no quotidiano individual das relações em saúde.

Tratam-se dos mesmíssimos princípios gerais. Nas relações concretas os desvios residem até nas perigosas práticas eivadas da banalidade do mal, teorizando o que se me oferece teorizável, para o exercício médico-medicamentoso frente a nosologias ou patologias ou desafios. E tudo igual quando frente a pacientes. Arendt não deixou de postular respostas utilitaristas para questões candentes, designadamente no que concerne às virtudes das decisões subjacentes (ou respostas particulares para questões particulares). Assim, segundo Khon, quando (finais dos anos 60) foi questionada por alunos seus sobre se deviam aceitar o desafio para cooperar com trabalhadores dos sindicatos na oposição à guerra no Vietname, ouviram com surpresa a fundamentação da

\footnotetext{
${ }^{28}$ Assim Sánchez Madrid, Crisis, p. 488 e parece igualmente resultar das leituras de Arendt, por exemplo, Responsabilidade e Juízo (Jerome Khon), D. Quixote, Lisboa, 2007, pp. 109-111, onde, contudo, não deixa de se questionar: «[... uma vontade dividida contra si própria é a menos adequada para a tarefa de agir, ao passo que um espírito dividido no seu próprio íntimo é o mais adequado para a tarefa da deliberação. Se é esta a maneira de ser da vontade que bem poderá a vontade fazer? E todavia, sem querer, como poderei eu ser alguma vez movido a agir?]».

${ }^{29}$ Sem coincidências, também o discurso nestes aspectos mais gerais usa muitas vezes conceitos que são familiares no contexto das concretas relações sociais e jurídicas aqui abordadas, parecendo-me muito oportuna a seguinte citação de Arendt, apud Sánchez Madrid, Crisis, p. 494, nota 40: Sobre la desobediencia civil (1998: 101): “["El espíritu de las leyes", como lo vio Montesquieu, es el principio por el cual actúan y se ven inspiradas a actuar las personas que viven bajo un específico sistema legal. El asentimiento, el espíritu de las leyes americanas, está basado en la noción de un contrato que liga recíprocamente, que establecieron primero las colonias individuales y después la Unión. Un contrato presupone una pluralidad de por lo menos dos, y cada asociación establecida y actuante según el principio del asentimiento, basado en la promesa mutua, presupone una pluralidad que no se disuelve sino que se conforma en una unión -e pluribus unum. Si los miembros individuales de la comunidad formada decidieran no conservar una restringida autonomía, si decidieran desaparecer en una completa unidad tal como la union sacrée de la nación francesa, todo lo que se pudiera decir acerca de la relación moral del ciudadano con la ley sería mera retórica. El asentimiento y el derecho a disentir se han convertido en los principios inspiradores y organizadores de la acción que han enseñado a los habitantes de este continente "el arte de asociarse juntos", del que proceden esas asociaciones voluntarias cuyo papel fue Tocqueville el primero en advertir, con sorpresa, admiración y algún recelo; las consideraba la fuerza peculiar del sistema político americano]".
} 
resposta de «senso comum»: - Pois sim! Dessa forma podem usar as policopiadoras dos sindicatos ${ }^{30}$. Eis uma solução plausível. Perigosa e tentadora.

\section{Uma legiferação pragmática ou uma singularidade disciplinar?}

Não penso que as soluções de bom senso suscitem fundações diferentes para uma racionalidade séria. As evidências quando são úteis são sérias e a seriedade partilha com a viabilidade a exigência de um espírito propenso a ver a autoridade onde é pressuposto esta autoridade existir. É mister entregar a decisão judicial ao juiz, a investigação ao cientista, o que é médico ao profissional de saúde, etc. Uma convicção que transporta certeza, celeridade e um máximo de eficiência. Posto isto, perante a proficiência carregase o modelo de utilidade e maximiza-se o bem-estar. E não se diga que a conduta daquela autoridade se expõe à crítica da sedução pelo poder, pois aquela não tem de forçosamente de ser tutelada por este, sendo certo que se a autoridade se justificar para a acção, então o poder, puro e duro, será parte possível de uma solução a não ser descartada. Mas basta colocar a regra de reconhecimento em jogo para afastar o incómodo das sombras que sempre assustam. A autoridade ganha matizes de persuasão e de convencimento, exista ou não diálogo associado, pois a autoridade por si só se basta. Mesmo aceitando o pressuposto de que é possível explicar e fazer-se entender ${ }^{31}$, restará sempre apurar se há tempo e qual a utilidade. Em um momento as questões repetidas tornam-se redundantes, meramente insolentes e a afirmação autojustifica-se ${ }^{32}$ : é assim... por que assim é. Afirma-

\footnotetext{
${ }^{30}$ Khon: introdução a Responsabilidade e Juízo, p. XI; sobre a banalidade do mal, pp. XIII ss; da A: Ditadura e responsabilidade pessoal, pp. 15 ss.

${ }^{31}$ Generalizo o «desabafo» de Clara Pinto Correia, Clones Humanos: a nossa autobiografia colectiva, Relógio d'Água, 1999, p. 30, sobre a ausência de uma noção de «urgência e de nobreza» nessa tarefa de os cientistas -e técnicos-explicarem, de se exporem. A sofisticação dos conhecimentos é enorme e as exigências do entendimento também, as informações prestadas são recolhidas e processadas muitas vezes pela comunicação social com deformações inerentes a uma insuficiente compreensão e coloridas pela necessidade de captar quotas de atenção no mercado: uma mistura explosiva de ignorância que provoca muito naturalmente a retracção dos cientistas e dos técnicos. Basta ver a repulsa deontológica institucional da generalidade das corporações profissionais perante a exposição mediática dos seus membros.

32 É o que ensina Lonergan sobre a reflexão prática que antecede a decisão (pp. $704 \mathrm{ss):} \mathrm{o} \mathrm{processo} \mathrm{de}$ reflexão não possui, por si só, um momento final a que se sucede a decisão. Por regra, antes de se esgotar a reflexão — se tanto acontecer- interpõe-se a oportunidade ou a imposição da decisão ou pelo menos a tentação eficaz de um voluntarismo perante uma opção razoável. Os dois momentos podem até ser antinómicos, entrar em conflito. Para a conformação da norma é a decisão que avulta; para aquilatar esta avultará o mecanismo reflexivo e o respectivo iter: um juízo. Ou seja, existe uma distinção a formular-a precisar - entre decisão e juízo: aquela conforma racionalmente a realidade ao passo que este conforma racionalmente aquela conformação.
} 
o quem o possa fazer. Permito-me invocar aqui o paralelismo com os fundamentos da certeza e da segurança que alicerçam a intervenção judicial: consoante a alçada do tribunal, existirá um momento em que se encerram as discussões em foro, com o trânsito em julgado da decisão. As semelhanças com a saúde ocorrem imediatamente. No mesmo esteio também ao profissional de saúde é apelativa a decisão tecnicamente irrepreensível, a despeito da inequívoca decisão contrária do visado. O reduto moral ou ético suga-nos para a solidariedade e nesta se encontra um oceano de excelentes intenções onde o receio da responsabilidade mingua face à substituição das decisões. A panaceia jurídica é a justificação da ilicitude da conduta se forem reivindicadas responsabilidades. Parece simples. Eis uma das reduções radicais que confronta com as questões de ser indiferente pensar —também em senso comum - sobre a eventual dosimetria terapêutica de uma intervenção que modifique os seios, as maçãs do rosto ou os lábios; ou se devo promover algum de tipo de acção invasiva (constrangedora), ou, ao menos, responsabilizar o alcoólico, o obeso ou o fumador que desprezem as prescrições sobre a alteração dos seus hábitos e permaneçam cronicamente em lista de abuso dos serviços de saúde pública; ou o paciente que revoga consentimento, iniciados os procedimentos da intervenção, para visionar partida desportiva. E aquele outro indignado com a cicatriz traçada no corpo em resultado da intervenção que podia ser laparoscópica? Não optou, afirma... Tudo menos ou mais complicado, mais ou menos absurdo, e com respostas onde a perspectiva jurídica também se intromete, seja sobre o que fazer, seja sobre o que foi feito.

Como se vê, seja por via da relevância da decisão paternalista, seja pelo paternalismo da decisão relevante, a banalidade do mal aparece a estreitar os dois leitos do rio, onde quer que se coloque a autoridade. Assiste aos profissionais de saúde e ao paciente, tal como se pretende, respectivamente, a obediência a um escrupuloso executor administrativo e deitam-se preces para que a teimosia não obnubile ao visado a decisão racionalmente proveitosa. A eficácia constitui um excelente critério para o que é jurídico, mas para uma validade de conteúdo material, que não meramente formal, persistirá sempre intocável o dever de respeito perante a dignidade jurisgénica individual? Onde se cantam hoje odes à liberdade não se invectivarão amanhã os venenos dos egoísmos intoleráveis? E vice-versa? Hão-de ser os casos contados e tipificados das excepções e da equidade e dos instrumentos de justificação da ilicitude com que se sanará muita intervenção em que se inundem os diques. Está bem de ver que a autoridade a que se 
acolhe o determinismo útil de uma actuação plausível que reduz a vontade de alguém subalternizado perante o saber fazer não é forçosamente unívoca, mas contingente. Vários juristas e vários juízes conduzem a várias autoridades; um arquitecto versus um engenheiro versus um empreiteiro hábil, conferem opções face a uma empreitada em que persistem autoridades equivalentes perante o interessado. O processo de intelecção acaba por revelar várias alternativas logo pela banda de quem é inquirido para exercitar uma opinião revestida de autoridade. As limitações recíprocas subsistem consoante a variação das perspectivas. A medicina não difere nisto, e perante os vários cursos de acção possíveis e sobretudo as sequelas conjecturáveis não será de atribuir autoridade exactamente a quem as recebe no regaço? Não é isto igualmente reduto de autoridade a opor aos outros actores? Pois essa autoridade que o paciente possui será a que sobra das muitas virtudes do que tem de tolerar, usando aqui a expressão com especial vigor etimológico ${ }^{33}$, o qual se ilustra facilmente pedindo emprestada o aforismo de La Rochefoucould: «Nous avons tous assez de force pour supporter les maux d'autrui.» ${ }^{34}$.

Mas não só. Reside por cima de tudo no próprio homem o esforço permanente para procurar garantir a sua própria humanidade. Assim animam as leituras inspiradoras de Castanheira Neves sobre o Direito, perspectivado como:

um dos modos de transcender-se o homem a si próprio: o transcender-se num projecto-de-ser que fundamenta a sua humana co-existência; a tarefa de (o projecto e o esforço de) a axiológica humanização do homem na sua realidade de convivência histórica ${ }^{35}$.

\footnotetext{
${ }^{33}$ Penso nos sinónimos etimológicos do verbo tolerare, «suportar» ou «aguentar». Segundo Rui Tavares, serve exactamente como exemplo de uma utilização com curso na dor que o paciente suporta e a medicina visa atalhar "[não uma coisa que se fazia de bom ânimo, mas a que restava a fazer se não havia qualquer alternativa]", Apresentação a Cândido ou o Optimismo e O Tratado sobre a Tolerância, de Voltaire, Tinta-daChina, 2008, pp. XI-XXV, máx, XVIII. Problematizando sobre a circunscrição da tolerância às «questões de opinião", i.e., onde exista álea que convoque ponderações e as fronteiras das respectivas limitações (designadamente quanto à passividade, admitindo com Karl Popper a faculdade de recusar e combater a intolerância, pela força, se necessário, repudiando a incitação insidiosa — criminosa - à tolerância para fins perniciosos). Valiosas citações: Compte-Sponville, pp. 173-189. Delimitando negativamente, Michel Meyer, La Insolencia: ensayo sobre la moral, Cap. IV e V.

34 Rochefoucauld: Maximes et Réflexions Morales du Duc de La Rochefoucauld, Paris, Ménard et Desenne Fils, 1817 (open library: http://www. archive.org/details/maxmesetrflex00larouft ), XIX, p. 5.

35 António Castanheira Neves, O papel do jurista no nosso tempo, in BFDUC, 44, 1968, pp. 83-142, maxime p. 52.
} 
O que leva expressamente Capelo de Sousa a considerar como condição de um efectivo e extenso exercício do direito geral de personalidade não deverem os respectivos titulares descurar a adequada firmeza perante compressões ou eventuais violações ${ }^{36}$.

Não parece fácil quer por banda da evolução científica da medicina, e da biologia, e das conquistas tecnológicas aplicáveis, quer por banda das Relações Internacionais, das alterações geopolíticas que conformam os Estados e alteram fronteiras, quer por banda dos comportamentos sociais localizados (antropologia) ou generalizados (sociologia), e tudo resulta em outro quebra-cabeças face à distribuição de recursos e repartição de meios que são escassos perante necessidades sociais de primeira grandeza e prioridade em uma comunidade global crescente. Tudo se projecta no Direito e este mal se propõe regular logo encontra modificações significativas nos bens e nas pessoas cujas tensões e litígios deve aplacar. Desta forma as reacções entre todos estes movimentos de placas provocam compressões e deslizamentos, tantas vezes com fracturas e inconformismos. As sucessivas erupções que se foram precipitando em ritmo progressivamente acelerado por via do galopante percurso da Humanidade criam retalhos que vão sendo sucessivamente cerzidos através do que é consensual ou do que se mostra possível ou aceitável estabelecer por compressão. Uma enorme tarefa onde a normação e sobretudo a actividade jurisprudencial se mostram instrumentos indispensáveis para atalhar os efeitos indesejados de uma imensidão de forças contrárias.

Tenho por razoável que os exemplos expostos hão-de vergar-se a uma contingentação própria da aplicação dos conceitos e dos princípios gerais enunciados sobre o ser humano e a solidariedade em que se projecta a consciência individual. São estes que permitem a funcionalidade do juízo nos processos de integração e de solução dos contrários. Sempre que o legislador ou o juiz caiam em indecisão ou tentação de os arredar, logo aos conceitos se sucedem os preconceitos e ditam estes uma indisciplina onde o empirismo casual vira casuísmo. O problema reside então em evitar extrair daqui paradigmas falaciosos para valores ou ditames decisionistas. O mesmo é dizer: pela delimitação negativa se detecta igualmente a necessidade da construção disciplinar autónoma do Direito da Medicina.

${ }^{36}$ Rabindranath Capelo de Sousa, O Direito Geral de Personalidade, Coimbra, 1995, p. 625. 


\section{Referências}

1 Hannah A, Sobre el imperialismo, La tradición oculta Paidós, Barcelona: Paidós, 2004.

2 Cardoso da Costa J O Princípio da Dignidade da Pessoa Humana na Constituição e na jurisprudência Constitucional Portuguesas, AA.VV, Direito Constitucional: Estudos em Homenagem a Manoel Gonçalves Ferreira Filho, Dialética, São Paulo, 1999.

3 Hannah Arendt, A Condição Humana, Relógio d'Água, 2001.

Recebido em: 18/9/2016

Aprovado em: 29/9/2016

Como citar este artigo:

Rodrigues JV. Fragmentos axiológicos e eixos de afirmação do Direito da Medicina. Revista Cadernos IberoAmericanos de Direito Sanitário. 2016 dez., 5 supl. 1:77-99. 